\title{
HIBRIDISASI BUATAN KACANG TANAH DAN FENOTIPE KARAKTER TIPE PERTUMBUHAN, UKURAN POLONG, DAN JUMLAH BIJI PER POLONG TANAMAN F1 HASIL HIBRIDISASI
}

\author{
Artificial Hybridization of Peanut and the Phenotype of F1 Plants for the Characters \\ of Growth Habits, Pod Size, and the Number of Seeds per Pod
}

\author{
Setyo Dwi Utomo*, Kuswanta Futas Hidayat, Akari Edy, Nyimas Sa'diyah, \\ Rizki Indriyani, Emma Halimaturosidah, Herlin Yustina
}

\author{
Jurusan Agronomi dan Hortikultura, Fakultas Pertanian, Universitas Lampung \\ Jl. Sumantri Brojonegoro No 1 Gedung Meneng, Bandar Lampung 35145 \\ *E-mail Korespondensi: setyo.dwiutomo@fp.unila.ac.id
}

\begin{abstract}
ABSTRAK
Perakitan varietas unggul kacang tanah dapat dilakukan melalui tahapan- tahapan perluasan genetik populasi, inbreeding, seleksi, dan uji daya hasil. Keragaman genetik dapat dibangun atau diperluas antara lain melalui hibridisasi (persilangan) seksual. Penelitian ini bertujuan untuk mengetahui: (1) tingkat efisiensi keberhasilan hibridisasi buatan K/SR 3 atau NC 7 dengan sembilan varietas unggul nasional; (2) aksi gen yang mengendalikan karakter ukuran polong, jumlah biji per polong dan tipe pertumbuhan kacang tanah. Penelitian ini terdiri atas dua percobaan yaitu hibridisasi dan evaluasi tipe pertumbuhan famili $F_{1}$. Percobaan dilakukan di rumah kaca dan Laboratorium Lapang Terpadu Fakultas Pertanian, Universitas Lampung. Varietas yang disilangkan meliputi genotipe atau varietas unggul nasional yang tumbuh tegak (Bima, Bison, Gajah, Jerapah, Talam, Kelinci), dan genotipe introduksi K/SR-3 (tumbuh menjalar) dan NC 7 (tumbuh setengah menjalar). Hasil penelitian menunjukkan bahwa ratio jumlah ginofor (JG) / jumlah bunga yang disilangkan (JB) tertinggi ditunjukkan oleh persilangan NC 7 x Bison sebesar 31\%; ratio jumlah polong (JP) / JG tertinggi oleh NC 7 x Kelinci sebesar 78\%; dan ratio JP/JB tertinggi oleh Bima x NC 7 sebesar 13\%. Persentase tanaman $\mathrm{F} 1$ yang menunjukkan tipe pertumbuhan setengah menjalar sebanyak $85 \%$, berpolong biji dua sebanyak $100 \%$, dan berpolong besar sebanyak $89 \%$.
\end{abstract}

Kata kunci: Efisiensi hibridisasi, ukuran polong, jumlah biji, tipe pertumbuhan

\section{ABSTRACT}

The development of superior peanut cultivars can be conducted through the steps of enhancement of genetic variation, inbreeding, selection, and yield trials. Genetic variation can be enhanced through sexual hybridization (crossing). The objectives of this study were 1) to determine the rate of success of artificial hybridization between runner/semi-runner and Spanish/upright type of peanut; 2) to know the phenotypic characters of the growth habit, pod size, and number of seeds per pod in peanuts. The F1 phenotype is related to the estimation of gene action. This study consisted of two experiments, namely hybridization and evaluation of the type of growth of the F1 family. The experiment was conducted in the Integrated Field Laboratory, Faculty of Agriculture, University of Lampung. The genotypes of parents included national cultivars Bima, Bison, Gajah, Jerapah, Talam, and Kelinci; and introduced runner/semi-runner genotypes K/ SR-3 (runner) and NC 7 (semi-runner). The results showed that NC $7 \mathrm{x}$ Bison showed the highest ratio of the number of gynophores (NG) / number of flowers crossed (NFC) (31\%); NC 7 x Kelinci showed the highest number of pods (NP) / NG ratio (78\%); and Bima $x$ NC 7 showed the highest NP / NFC (13\%). The percentage of F1 plants showing semi-runner growth habit was $85 \%$, producing pods with two seeds was $100 \%$, and producing large pods was $89 \%$.

Keywords: Growth habit, pod size, the rate of artificial hybridization, seed number 


\section{PENDAHULUAN}

Upaya peningkatan hasil kacang tanah dapat dilakukan melalui kegiatan pemuliaan tanaman untuk merakit varietas unggul. Perakitan varietas unggul dapat dilakukan melalui tahapan- tahapan yaitu perluasan genetik populasi, inbreeding, seleksi, dan uji daya hasil (Utomo, 2012; Nurhartanto, 2006; Kasno, 1993). Keragaman genetik dapat dibangun atau diperluas antara lain dengan melakukan hibridisasi seksual. Hibridisasi bertujuan mendapatkan kombinasi genetik yang diinginkan melalui persilangan bunga dua atau lebih tetua yang berbeda genotipenya Kegiatan hibridisasi buatan harus efisien untuk mendapatkan individu beragam dalam jumlah banyak. Dalam hibridisasi buatan, tepung sari dipertemukan dengan kepala putik. Faktorfaktor yang mempengaruhi efektivitas dan efisiensi hibridisasi meliputi ketepatan waktu berbunga, waktu emaskulasi, dan waktu penyerbukan (Kasno, 1993). Setelah diperoleh benih F1 hasil persilangan, informasi tentang pewarisan karakter agronomi sangat diperlukan dalam rangka mempermudah pelaksanaan seleksi. Studi tentang pewarisan karakter agronomi pada tanaman kacang tanah dilaporkan oleh Sinclair et al. (2018), yaitu tentang pewarisan karakter laju transpirasi.

Karakter agronomis untuk mendukung daya hasil tinggi antara lain polong besar dan jumlah polong. Jumlah polong kacang tanah berkaitan dengan tipe pertumbuhan tanaman yaitu menjalar, setengah menjalar, dan tegak (Utomo et al., 2005). Tanaman kacang tanah yang memiliki tipe pertumbuhan menjalar atau setengah menjalar menghasilkan ginofor yang mencapai tanah lebih banyak sehingga jumlah polong lebih banyak dan produktivitas lebih tinggi. Menurut Balaiah et al (1977) dan Singh dan Oswalt (1991) jumlah biji kacang tanah yang kurang dari 3 biji per polong dominan terhadap kacang tanah dengan 3 atau lebih biji per polong; kacang tanah yang memiliki 2 biji per polong dominan terhadap kacang tanah yang memiliki 3 atau 4 biji per polong. Polong berukuran besar dominan terhadap ukuran polong kecil. Badami et al. (1928) dalam Wynne et al. (1982) tentang karakter kualitatif pada kacang tanah menjelaskan bahwa tipe pertumbuhan menjalar pada tanaman kacang tanah dominan terhadap tipe pertumbuhan tegak sedangkan menurut Balaiah et.al. (1977) dan Wynne et al. (1982) tipe pertumbuhan setengah menjalar (semi-spreading) pada tanaman kacang tanah dominan terhadap tipe menjalar (spreading) dan tipe tegak (erect). Agar seleksi untuk merakit varietas unggul kacang tanah lebih efektif, perlu dilakukan studi pewarisan sifat (Sinclair et al., 2018). Tujuan penelitian ini adalah: (1) mengetahui tingkat efisiensi keberhasilan hibridisasi buatan kacang tanah; (2) mengetahui fenotipe karakter tipe pertumbuhan, ukuran polong, dan jumlah biji per polong pada kacang tanah. Fenotipe F1 terkait dengan pendugaan aksi gen.

\section{METODE PENELITIAN}

Penelitian ini terdiri atas dua percobaan yaitu Percobaan I : hibridisasi antar-tetua, dan Percobaan II : evaluasi tipe pertumbuhan tanaman $F_{1}$. Penanaman dilakukan di rumah kaca dan laboratorium lapang terpadu Fakultas Pertanian, Universitas Lampung. Benih yang digunakan adalah benih tetua varietas Bima, Gajah, Jerapah, Talam, Kelinci, Bison dan benih tetua introduksi K/SR-3 dan NC 7.

\section{Percobaan I: Hibridisasi Buatan}

Percobaan I dilaksanakan di rumah kaca Fakultas Pertanian, Universitas Lampung. Galur yang disilangkan atau dilakukan hibridisasi adalah NC 7 dan K/SR-3; galur-galur tersebut memiliki tipe pertumbuhan menjalar dan setengah menjalar, serta ukuran biji (berdasarkan bobot, panjang dan lebar biji) lebih besar daripada varietas unggul nasional Gajah, Bima, Jerapah, Talam, Bison, Kelinci. Kombinasi persilangan ditunjukan oleh 
Tabel 1 dan 2. Dalam satu polibag ditanam masing-masing satu tetua.

Dalam hibridisasi buatan, dilakukan penyerbukan secara terarah, yaitu mempertemukan tepung sari dengan kepala putik. Tahapan hibridisasi buatan antara lain persiapan, emaskulasi, penyerbukan, pelabelan, dan pendektesian keberhasilan hibridisasi buatan. Alat yang digunakan dalam hibridisasi meliputi gunting, pinset berujung runcing, kertas label, dan alkohol $70 \%$. Tahap selanjutnya adalah emaskulasi, yaitu kegiatan pembuangan organ kelamin jantan (stamen) pada tetua betina sebelum bunga mekar atau sebelum terjadi penyerbukan sendiri. Hal pertama yang harus dilakukan yaitu pilih kuncup bunga yang akan mekar pada besok paginya untuk diemaskulasi. Kemudian mahkota kuncup bunga dibuka dengan menggunakan pinset sampai semua kotak sari terlihat jelas dari luar. Kotak sari dibuang satu menggunakan pinset. Pekerjaan ini harus dilakukan dengan hati-hati, agar putik tidak ikut terpotong atau rusak. Bunga yang tidak diemaskulasi dibuang. Selanjutnya, bungabunga yang telah diemaskulasi diberi label sebagai tanda untuk tahap selanjutnya yaitu penyerbukan. Penyerbukan adalah peletakan polen ke kepala putik. Penyerbukan dilakukan pada pagi hari sekitar jam 06.00 - 08.00. Polen dari tetua jantan ditempelkan pada kepala putik tetua betina menggunakan pinset. Setelah dilakukan penyerbukan, pada tangkai bunga segera dipasangkan label yang telah diberi keterangan tanggal penyerbukan. Tahap terakhir yaitu pendeteksian keberhasilan hibridisasi buatan (F1). Hibridisasi buatan berhasil ditandai dengan terbentuknya ginofor; diamati pada 5-7 hari setelah penyerbukan (Kasno,1993).

Variabel yang diamati meliputi tingkat keberhasilan hibridisasi dihitung dengan rumus:

a. Ratio jumlah ginofor yang dihasilkan dibagi jumlah bunga yang disilangkan $\left(\right.$ Ratio JG/JB) $=\frac{\sum \text { ginofor yang dihasilkan }}{\sum \text { bunga yang disilangkan }}$ $\mathrm{x} 100 \%$

b. Ratio jumlah polong yang dihasilkan dibagi jumlah ginofor yang dihasilkan $($ Ratio JP/JG $)=\frac{\text { E polong yang dihasilkan }}{\sum \text { ginofor yang dihasilkan }}$ x $100 \%$

c. Ratio jumlah polong yang dihasilkan dibagi jumlah bunga yang disilangkan $($ Ratio JP/JB $)=\frac{\text { E polong yang dihasilkan }}{\sum \text { bunga yang disilangkan }}$ x $100 \%$

\section{Percobaan II}

Percobaan II terkait genotipe kacang tanah yang diuji meliputi tanaman $F_{1}$ kacang tanah keturunan hasil hibridisasi pada Percobaan I. Karakter yang diamati adalah tipe pertumbuhan, jumlah biji per polong, dan ukuran polong diamati dan dibandingkan dengan tetua jantan dan betina. Setiap individu benih F1 ditanam di lahan, satu benih per lubang. Jarak tanam $50 \times 50 \mathrm{~cm}$.

\section{HASIL DAN PEMBAHASAN}

\section{Tingkat Keberhasilan Hibridisasi}

Hasil hibridisasi buatan kacang tanah menunjukkan bahwa ratio jumlah ginofor yang terbentuk dari bunga betina yang disilangkan dibagi jumlah bunga yang disilangan (JG/JB) tertinggi terdapat pada persilangan $\mathrm{NC} 7 \mathrm{x}$ Bison sebesar $31 \%$. Ratio JP/JG tertinggi terdapat pada persilangan NC 7 x Kelinci sebesar 78\%, dan Ratio JP/JB tertinggi juga terdapat pada persilangan Bima x NC 7 sebesar $13 \%$ (Tabel 1).

Ratio JG/JB dan Ratio JP/JB terendah terdapat pada persilangan Kelinci x K/SR-3, sedangkan Ratio JP/JG terendah terdapat pada persilangan NC $7 \times$ Bison. Rata-rata persentase Ratio JG/JB adalah $18 \%$. Menurut Somaatmadja (1981) dalam Trustinah (1993), ginofor yang jaraknya cukup jauh dari permukaan tanah (sekitar 15 $\mathrm{cm})$ umumnya tidak bisa mencapai tanah 
dan ujungnya akan mengering dan mati. Rata-rata persentase Ratio JP/JG sebesar $45 \%$.

Pada stadia pembentukan polong masih berkaitan dengan ginofor-ginofor yang terbentuk dan telah masuk ke dalam tanah. Pembentukan polong dimulai ketika ujung ginofor mulai membesar sampai mencapai ukuran maksimum. Menurut Othman et al. (1979) dalam Lim dan Gumpil (1984), kacang tanah merupakan tanaman yang secara alami menyerbuk sendiri akan membutuhkan sedikit bantuan serangga. Namun telah dilaporkan bahwa hanya kurang dari $10 \%$ dari banyak bunga yang dihasilkan, berkembang menjadi polong matang.

Rata-rata persentase Ratio JP/JB atau keberhasilan hibridisasi pada penelitian adalah 8\%. Hal ini menunjukkan bahwa tingkat efisiensi keberhasilan hibridisasi rendah. Menurut Halim et al. (1980) dalam Lim dan Gumpil (1984) dalam hibridisasi kacang tanah, teknis dan waktu emaskulasi serta pengaruh tetua pada hasil penyerbukan merupakan pertimbangan penting. Fase pembentukan ginofor dan fase pembentukan polong berkaitan dalam menentukan keberhasilan suatu hibridisasi. Setelah ginofor masuk ke dalam tanah dan membesar akan menghasilkan polong, setelah polong mencapai ukuran maksimal akan dimulai pembentukan biji dan berlangsung sampai bagian dalam polong terisi biji (biji penuh).

Dalam hibridisasi kacang tanah, teknik dan waktu emaskulasi serta pengaruh tetua pada hasil penyerbukan buatan telah dilaporkan bervariasi $38-70 \%$ tergantung pada teknik yang digunakan dan efisiensi operator (Halim et al., 1980 dalam Lim dan Gumpil, 1984). Polong yang terbentuk dalam penelitian ini jumlahnya sedikit dibandingkan dengan jumlah bunga yang telah disilangkan. Hal ini didukung oleh pernyataan Kasno (1993) tentang faktor faktor yang mempengaruhi suatu hibridisasi buatan antara lain ketepatan waktu berbunga, waktu emaskulasi, dan waktu penyerbukan.

Tabel 1. Tingkat keberhasilan hibridisasi buatan kacang tanah.

\begin{tabular}{llcccccc}
\hline $\begin{array}{c}\text { Tetua } \\
\text { Betina }\end{array}$ & $\begin{array}{c}\text { Tetua } \\
\text { Jantan }\end{array}$ & $\begin{array}{c}\text { Jumlah bunga } \\
\text { yang } \\
\text { disilangkan (JB) }\end{array}$ & $\begin{array}{c}\text { Jumlah } \\
\text { ginofor } \\
(\mathrm{JG})\end{array}$ & $\begin{array}{c}\text { Jumlah } \\
\text { polong } \\
(\mathrm{JP})\end{array}$ & $\begin{array}{c}\text { Ratio } \\
\text { JG/JB } \\
(\%)\end{array}$ & $\begin{array}{c}\text { Ratio } \\
\text { JP/JG } \\
(\%)\end{array}$ & $\begin{array}{c}\text { Ratio } \\
\text { JP/JB } \\
(\%)\end{array}$ \\
\hline NC 7 & Talam & 80 & 14 & 6 & 18 & 43 & 8 \\
NC 7 & Jerapah & 56 & 6 & 2 & 11 & 33 & 4 \\
NC 7 & Bison & 32 & 10 & 1 & 31 & 10 & 3 \\
NC 7 & Kelinci & 63 & 9 & 7 & 14 & 78 & 11 \\
Bima & NC 7 & 56 & 12 & 7 & 21 & 58 & 13 \\
Talam & K/SR-3 & 19 & 5 & 2 & 26 & 40 & 11 \\
Jerapah & K/SR-3 & 44 & 5 & 3 & 11 & 60 & 7 \\
Gajah & K/SR-3 & 37 & 10 & 4 & 27 & 40 & 11 \\
Kelinci & K/SR-3 & 44 & 3 & 1 & 7 & 33 & 2 \\
Rata-rata & & & & & 18 & 44 & 8 \\
\hline
\end{tabular}


Tabel 2. Tipe pertumbuhan tanaman F1

\begin{tabular}{|c|c|c|c|c|c|}
\hline \multirow{2}{*}{$\begin{array}{c}\text { Nomor } \\
\text { Persilangan } \\
\end{array}$} & \multicolumn{2}{|c|}{ Tetua betina } & \multicolumn{2}{|c|}{ Tetua jantan } & \multirow{2}{*}{$\begin{array}{c}\text { Tipe Pertumbuhan } \\
\text { tanaman F1 }\end{array}$} \\
\hline & Genotipe & $\begin{array}{c}\text { Tipe } \\
\text { pertumbuhan }\end{array}$ & Genotipe & Tipe pertumbuhan & \\
\hline 1 & Bima & Tegak & $\mathrm{NC7}$ & Setengah Menjalar & Mati \\
\hline 2 & Bima & Tegak & NC7 & Setengah Menjalar & Setengah Menjalar \\
\hline 3 & Bima & Tegak & NC7 & Setengah Menjalar & Mati \\
\hline 4 & Bima & Tegak & $\mathrm{NC7}$ & Setengah Menjalar & Setengah Menjalar \\
\hline 5 & Bima & Tegak & NC7 & Setengah Menjalar & Setengah Menjalar \\
\hline 6 & Bima & Tegak & NC7 & Setengah Menjalar & Setengah Menjalar \\
\hline 7 & Bima & Tegak & NC7 & Setengah Menjalar & Setengah Menjalar \\
\hline 8 & Bima & Tegak & NC7 & Setengah Menjalar & Mati \\
\hline 9 & Bima & Tegak & NC7 & Setengah Menjalar & Tegak \\
\hline 10 & Gajah & Tegak & K/SR-3 & Menjalar & Setengah Menjalar \\
\hline 11 & Gajah & Tegak & K/SR-3 & Menjalar & Setengah Menjalar \\
\hline 12 & Gajah & Tegak & K/SR-3 & Menjalar & Tidak Tumbuh \\
\hline 13 & Gajah & Tegak & K/SR-3 & Menjalar & Tegak \\
\hline 14 & Gajah & Tegak & K/SR-3 & Menjalar & Tegak \\
\hline 15 & Gajah & Tegak & K/SR-3 & Menjalar & Setengah Menjalar \\
\hline 16 & Gajah & Tegak & K/SR-3 & Menjalar & Mati \\
\hline 17 & Gajah & Tegak & K/SR-3 & Menjalar & Setengah Menjalar \\
\hline 18 & Gajah & Tegak & K/SR-3 & Menjalar & Setengah Menjalar \\
\hline 19 & Jerapah & Tegak & K/SR-3 & Menjalar & Setengah Menjalar \\
\hline 20 & Jerapah & Tegak & K/SR-3 & Menjalar & Setengah Menjalar \\
\hline 21 & Jerapah & Tegak & K/SR-3 & Menjalar & Tidak Tumbuh \\
\hline 22 & Jerapah & Tegak & K/SR-3 & Menjalar & Tidak Tumbuh \\
\hline 23 & Talam & Tegak & K/SR-3 & Menjalar & Setengah Menjalar \\
\hline 24 & Talam & Tegak & K/SR-3 & Menjalar & Setengah Menjalar \\
\hline 25 & Talam & Tegak & K/SR-3 & Menjalar & Setengah Menjalar \\
\hline 26 & Talam & Tegak & K/SR-3 & Menjalar & Setengah Menjalar \\
\hline 27 & Kelinci & Tegak & K/SR-3 & Menjalar & Setengah Menjalar \\
\hline
\end{tabular}

\section{Karakter Tipe Pertumbuhan}

Hasil penelitian menunjukkan bahwa 17 dari 20 tanaman F1 (85\%) tumbuh setengah menjalar, sedangkan tiga tanaman F1 (15\%) tumbuh tegak. Diduga alel yang mengendalikan karakter tipe pertumbuhan setengah menjalar dominan terhadap tipe pertumbuhan tegak (Tabel 2; Gambar 1 4). Menurut Badami et al. (1928) dalam Wynne et al. (1982), tentang karakter kualitatif pada kacang tanah dijelaskan bahwa tipe pertumbuhan menjalar pada tanaman kacang tanah dominan terhadap alel tipe pertumbuhan tegak sedangkan menurut Balaiah (1977) dalam Wynne et al. (1982), tipe pertumbuhan setengah menjalar (semispreading) pada tanaman kacang tanah dominan terhadap tipe menjalar (spreading) dan tipe tegak(erect). Hasil hibridisasi buatan yang masih memiliki tipe pertumbuhan tegak yaitu 15\%. Tipe pertumbuhan tegak ini kemungkinan 
disebabkan genotipe tetua tidak sepenuhnya homozigot.

\section{Karakter Jumlah Biji per Polong}

Jumlah biji per polong tanaman F1 sebanyak dua butir, mengindikasikan bahwa polong berbiji dua dominan terhadap polong berbiji empat. Hal ini didukung oleh pernyataan Balaiah et al. (1977) tentang jumlah biji kacang tanah yang lebih sedikit dari 3 biji per polong dominan terhadap kacang tanah dengan 3 atau lebih biji per polong sehingga kacang tanah yang memiliki 2 biji per polong dominan terhadap kacang tanah yang memiliki 3 atau 4 biji per polong.

\section{Karakter Ukuran Polong}

Sebanyak 8 per 9 tanaman F1 menghasilkan polong berukuran besar, sedangkan 1 per 9 tanaman F1 menghasilkan polong berukuran sedang (Tabel 4; Gambar 5). Diduga, karakter polong berukuran besar dominan terhadap polong berukuran kecil. Data tersebut sesuai dengan laporan Balaiah et al. (1977) kacang tanah ukuran polong besar dominan terhadap ukuran polong kecil.

Tabel 3. Jumlah biji per polong tanaman F1 dan ketua tetuanya

\begin{tabular}{ccccc}
\hline \multicolumn{2}{c}{ Tetua betina } & \multicolumn{2}{c}{ Tetua jantan } & $\begin{array}{c}\sum \text { biji per polong } \\
\text { tanaman F1 }\end{array}$ \\
Genotipe & $\sum$ biji per polong & Genotipe & $\sum$ biji per polong & 2 \\
NC 7 & 2 & Kelinci & 4 & 2 \\
Bima & 4 & NC 7 & 2 & \\
\hline
\end{tabular}

Tabel 4. Ukuran polong tanaman F1, tetua betina, dan tetua jantan

\begin{tabular}{cccccc}
\hline \multirow{2}{*}{$\begin{array}{c}\text { Nomor } \\
\text { Persilangan }\end{array}$} & \multicolumn{2}{c}{ Tetua betina } & \multicolumn{2}{c}{ Tetua jantan } & Ukuran polong \\
\cline { 2 - 4 } & Genotipe & Ukuran polong & Genotipe & Ukuran polong & tanaman F1 \\
\hline 1 & NC 7 & Besar & Kelinci & Sedang & Besar \\
2 & NC 7 & Besar & Kelinci & Sedang & Besar \\
3 & NC 7 & Besar & Kelinci & Sedang & Besar \\
4 & NC 7 & Besar & Bison & Kecil & Besar \\
5 & NC 7 & Besar & Talam & Kecil & Besar \\
6 & NC 7 & Besar & Talam & Kecil & Besar \\
7 & NC 7 & Besar & Talam & Kecil & Besar \\
8 & NC 7 & Besar & Talam & Kecil & Sedang \\
9 & NC 7 & Besar & Talam & Kecil & Besar \\
\hline
\end{tabular}



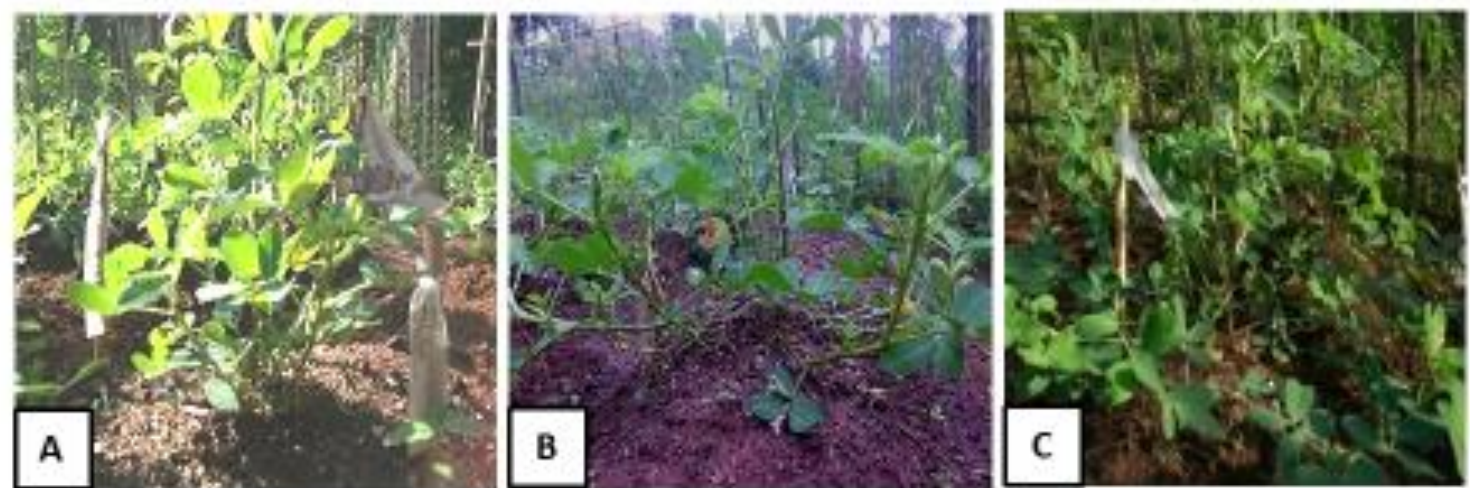

Gambar 1 Tipe pertumbuhan tanaman tetua betina (Bima), $F_{1}$ (Bima x NC 7), dan Tetua jantan (NC 7). Pengamatan dilakukan pada umur 1,5 bulan setelah tanam

A. Tetua betina (Bima) menunjukkan pertumbuhan tegak

B. $\mathrm{F}_{1}($ Bima $x \mathrm{NC} 7)$ menunjukkan pertumbuhan setengah menjalar

C. Tetua jantan (NC 7) menunjukkan pertumbuhan setengah menjalar
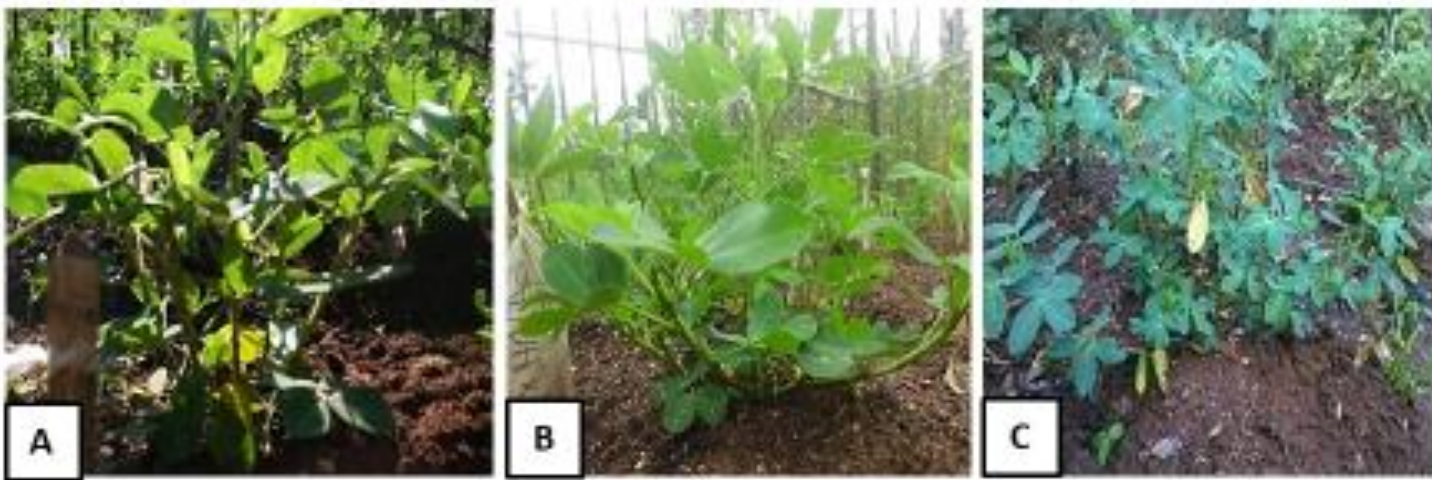

Gambar 2. Tipe pertumbuhan tanaman tetua betina (Gajah), $F_{1}$ (Gajah x K/SR 3), dan Tetua jantan (K/SR 3). Pengamatan dilakukan pada umur 1,5 bulan setelah tanam

A. Tetua betina (Gajah) menunjukkan pertumbuhan tegak

B. $F_{1}(G a j a h \times K / S R ~ 3)$ menunjukkan pertumbuhan setengah menjalar

C. Tetua jantan (K/SR 3) menunjukkan pertumbuhan menjalar
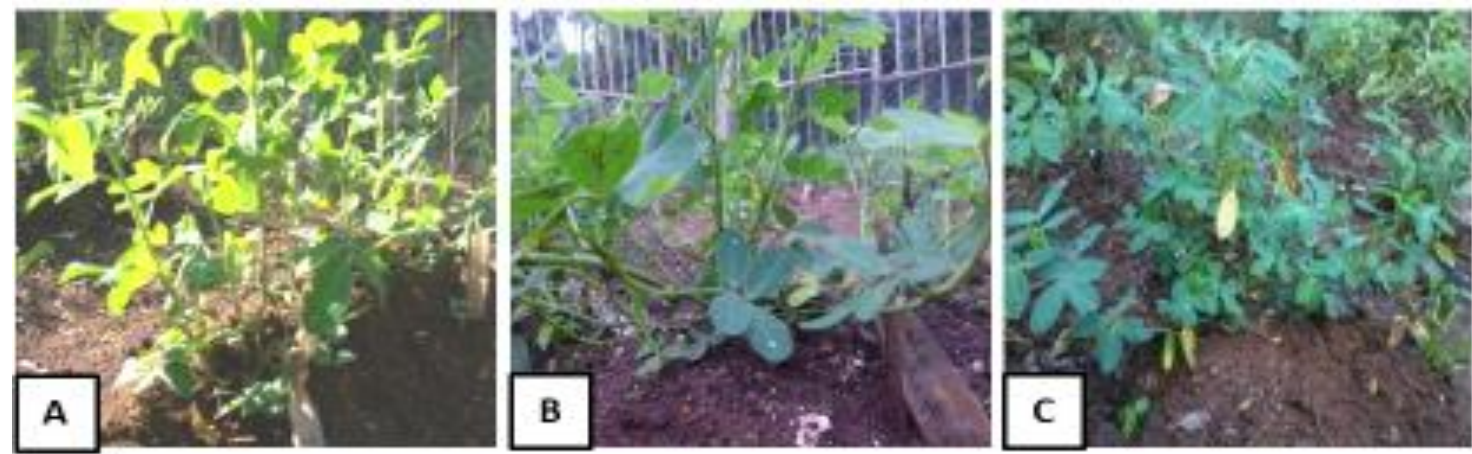

Gambar 3. Tipe pertumbuhan tanaman tetua betina (Jerapah), $F_{1}$ (Jerapah x K/SR 3), dan Tetua jantan (K/SR 3). Pengamatan dilakukan pada umur 1,5 bulan setelah tanam.

A. Tetua betina (Jerapah) menunjukkan pertumbuhan tegak

B. $F_{1}($ Jerapah $x$ K/SR 3) menunjukkan pertumbuhan setengah menjalar

C. Tetua jantan (K/SR 3) menunjukkan pertumbuhan menjalar 

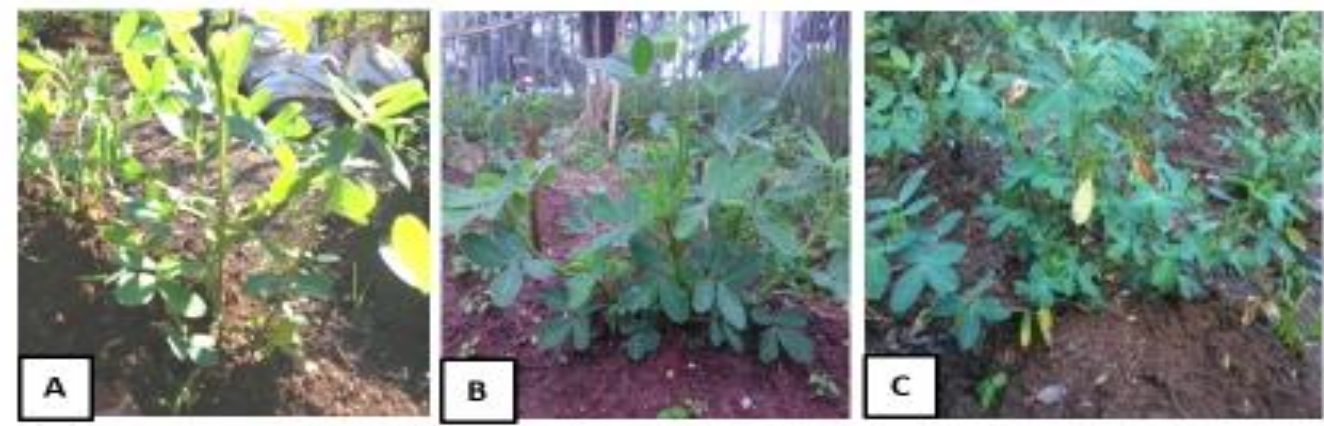

Gambar 4. Tipe pertumbuhan tanaman tetua betina (Talam), $F_{1}$ (Talam x K/SR 3), dan Tetua jantan (K/SR 3). Pengamatan dilakukan pada umur 1,5 bulan setelah tanam.

A. Tetua betina (Talam) menunjukkan pertumbuhan tegak

B. $F_{1}$ (Talam $x$ K/SR 3) menunjukkan pertumbuhan setengah menjalar

C. Tetua jantan (K/SR 3) menunjukkan pertumbuhan menjalar

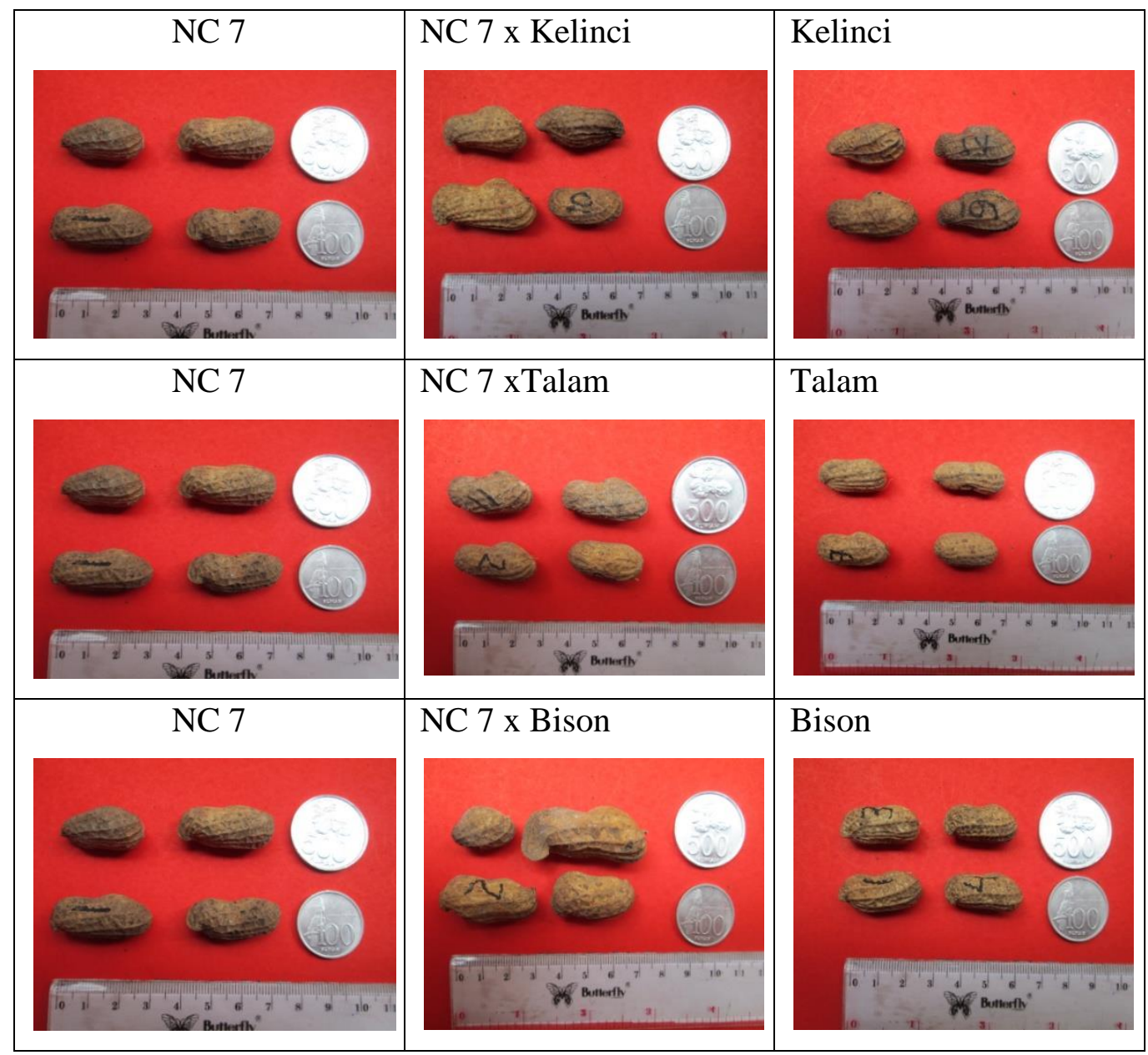

Gambar 5. Ukuran polong tanaman F1 dibandingkan dengan ukuran polong tetua betina dan tetua jantan. 


\section{KESIMPULAN}

Disimpulkan bahwa ratio jumlah ginofor (JG) / jumlah bunga yang disilangkan (JB) tertinggi ditunjukkan oleh persilangan $\mathrm{NC} 7 \times$ Bison sebesar 31\%; ratio jumlah polong (JP) / JG tertinggi oleh NC 7 x Kelinci sebesar 78\%; dan ratio JP/JB tertinggi oleh Bima x NC 7 sebesar $13 \%$. Persentase tanaman $\mathrm{F} 1$ yang menunjukkan tipe pertumbuhan setengah menjalar sebanyak $85 \%$, berpolong biji dua sebanyak $100 \%$, dan berpolong besar sebanyak $89 \%$.

\section{DAFTAR PUSTAKA}

Balaiah, C., P.S. Reddy, and M.V. Reddi. 1977. Genic analysis in groundnut. Proc. Indian Acad. Sci. 85 (5): 340-350. https://doi.org/10.1007/BF03052386.

Kasno, A. 1993. Pengembangan Varietas Kacang Tanah. Risalah Hsil Penelitian Kacang Tanah. Monograf Balittan Malang. No.12.

Lim, E.S. and J.S. Gumpil. 1984. The flowering, pollination and hybridization of groundnuts (Arachis hypogaea L.). Jurnal Pertanika, 7(2):61-66.
Nurhartanto, A. 2006. Evaluasi karakter agronomi kacang tanah (Arachis hypogaea L.) famili $F_{5}$ keturunan Perslangan Kelinci dan Florigiant. (Skripsi). Universitas Lampung. Bandar Lampung. $84 \mathrm{hlm}$.

Singh, Faujdar and D. L. Oswalt. 1991. Genetics and Breeding of Groundnut. Skill Development Series No. 4. ICRISAT.

Sinclair, T.R., D. Pradhan and A. Shekoofa. 2018. Inheritance of limited-transpiration trait in peanut: an update. Journal of Crop Improvement, $\quad 32(2)$ : 281-286. DOI:10.1080/15427528.2017.1420000.

Trustinah. 1993. Biologi Kacang Tanah. Risalah Hasil Penelitian Kacang Tanah. Monograf Balittan Malang. No.12: 9-23.

Utomo, S.D. 2012. Pemuliaan Tanaman Menggunakan Rekayasa Genetik. Lembaga Penelitian Universitas Lampung. Bandar Lampung. 144p.

Wynne, J. C. and T.A. Coffelt. 1982. Genetics of Arachis hypogaea L., p. 51-94. In H.E. Pattee and C.T.Young (eds.). Peanut Science and Technology. Amer. Peanut. Res. Educ. Soc., Inc. Yoakum, Texas, USA. 